\title{
Accounting Information Disclosure: Single versus Multiple Benchmark
}

\author{
Riza Praditha ${ }^{\mathrm{a}, *}$, Haliah $^{\mathrm{b}}$, Abdul Hamid Habbe ${ }^{\mathrm{b}}$, Yohanis Rura ${ }^{\mathrm{b}}$, Anas Iswanto Anwar ${ }^{\mathrm{b}}$ \\ ${ }^{a}$ STIE Tri Dharma Nusantara, Makassar, Indonesia \\ ${ }^{b}$ Faculty of Economic and Business, Universitas Hasanuddin, Makassar, Indonesia
}

\begin{abstract}
This study aims to analyze the level of estimation bias made by investors based on the form of disclosure of single and multiple benchmark accounting information. The research design uses an experimental laboratory (between-subject). Respondents in this study used 40 students who had attended capital market schools on the Indonesia Stock Exchange as a representation of novice investors. The results of hypothesis testing indicate that the disclosure of accounting information in the form of multiple benchmarks is better than the form of single benchmark information. This is indicated by the smaller error rate of estimation made by investors in predicting future earnings. Thus, the bias in decision making can be minimized by presenting more comprehensive accounting information using multiple benchmark forms.
\end{abstract}

Keywords: single benchmark, multiple benchmarks, accounting information

\section{INTRODUCTION}

Investors in making an investment decision are based on the expectation of making an earning. In other words, it can be said that investors prefer the realization of gains to the realization of losses (Sitinjak, 2013). Thus, investment decision making by investors should ideally be based on systematic and accurate stages. However, in many conditions, investors tend to experience heuristics in determining a decision. This is caused by bounded rationality so that the considerations taken tend to be a practical action using heuristic strategies (Alivia and Sulistiawan, 2010).

Heuristics can be interpreted as a "rule of thumb" that guides investors to act practically in estimating to allow bias in estimating (Habbe, 2017). The tendency of investors to predict intuitively combines prediction and distribution of impressions (Tversky and Kahneman, 1973). This means that the happy and sad feelings felt by investors will be able to influence the decisions that will be taken. In this condition, information plays its role as a basis for consideration in decision making.

All types of information available in the capital market have an important role in influencing the form of transactions carried out by investors who carry out further analysis of every

\footnotetext{
*Author in correspondence,

Email address: rizapradithaa@gmail .com (Riza Praditha)
}

ISSN: 2549-3221 (Print) 2549-323X (Online)

DOI: $10.26487 /$ hebr.v4i1.2352 announcement or accounting information provided on the exchange. The results of the analysis are used by investors in making decisions to choose an efficient investment portfolio (Wisudanto and Baihaqi, 2016). This is based on the signaling theory that information has value so that companies try to manage information in such a way that is by what the market expects (Rura, Y. and Subroto, B. and Sudarma, M. andRosidi, 2011).

Evidence of the importance of accounting information in decision making can be seen from a large amount of research on disclosure and analysis of financial statements. These analyzes have described the components and ratios of financial statements that can provide information about the company's profitability in the future (Ratmono and Cahyonowati, 2005). Disclosure of accounting information helps investors in estimating earnings before determining the investment to be taken. The importance of estimating earnings made by investors is a foundation in making investment decisions. Errors in estimating earnings (misestimated) will affect investors' decisions in trading on the exchange. Errors in estimating future earnings will have an impact on investor mistakes in determining the price of shares (mispriced) that will be sold or bought (Praditha, 2019).

Accounting information disclosure strategy is one of the things that need to be considered by company management because it will affect the amount of market response to the company. Generally, there are two forms of accounting information, namely the single benchmark disclosure strategy and mul- 
tiple benchmarks. The form of a single benchmark is a strategy for disclosure of accounting information in earnings announcements that only considers one benchmark, namely information on past earnings (historical earnings), while the multiple benchmark strategy is a strategy of information disclosure in earnings announcements that considers more than one benchmark, namely earnings of past periods (historical earnings) and future information in the form of management guidance (Wahyuni et al., 2016).

Several previous studies have tested the effectiveness of multiple benchmark information forms compared to single benchmark information forms (Schrand and Walther (2000); Krische (2005); Wahyuni and Hartono (2012); Wahyuni et al. (2016)). This is what underlies this research. The development of the results of previous studies is used as a reference in conducting further research by using comparative measurements of the earnings of all companies listed on the Indonesian stock exchange.

Estimated target earnings are calculated using Maximum Likelihood Estimation (Bloomfield et al. (2000); Habbe (2017); Sundari et al. (2018); Praditha (2019). The use of target earnings as comparative earnings is expected to be able to provide an error estimation rate made by investors so that the estimated bias that occurs can be measured and then compared between a single and multiple benchmark information forms.

\section{LITERATURE REVIEW AND HYPOTHESIS DEVEL- OPMENT}

\subsection{Multiple reference point theory}

The theory of multiple reference points (multiple referencepoint theory) proposed by Fiegenbaum et al. (1996) and Ordóez and Connolly (2000). The double point of reference theory predicts that individuals are influenced by three main dimensions in decision making namely the internal dimension, the external dimension, and the time dimension (past, present, and future), which is reflected in historical earnings information and future information in the current period earnings announcements.

Multiple reference point theory is one of the theories of psychology that was developed through the concept and practice of strategic reference points (SRP), better known as strategic benchmarks. In psychological research, benchmarks are referred to as comparative levels (Thibaut and Kelley, 2017), adjustment levels (Helson, 1964), or reference points (Kahneman and Tversky, 1979). Fiegenbaum et al. (1996) explained that the strategic reference point is the company's choice in helping to achieve strategic alignment. Strategic alignment is the compatibility between expected external environmental conditions and the internal capabilities of the company. SRP is developed from three dimensions, namely the company's internal conditions, the company's external conditions, and time dimensions that are oriented to the past, present, and future time.

SRP is built and developed from prospect theory and other relevant theoretical perspectives. Kahneman and Tversky (1979) demonstrate the theory of prospects that individuals use targets/reference points in evaluating choices. The behavior of

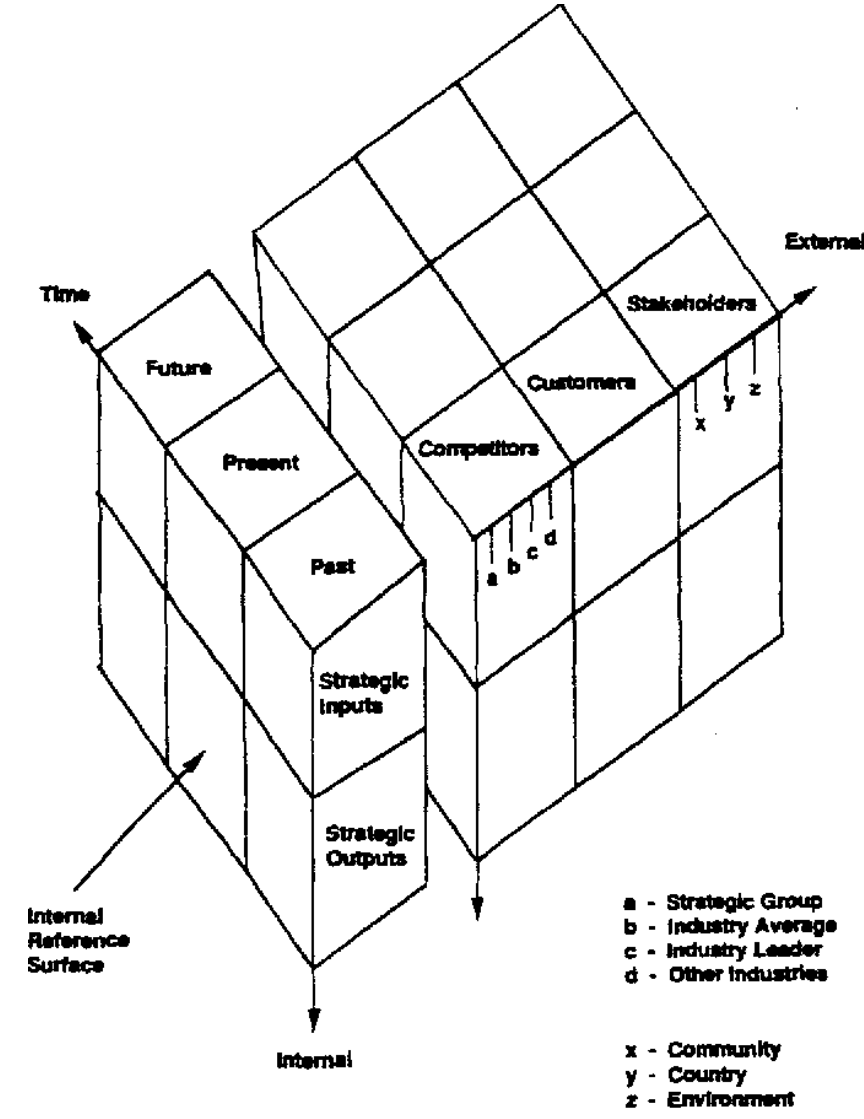

Figure 1: Strategic Reference Point Theory

Source: Fiegenbaum et al. (1996)

these individuals depends on whether they feel as the top (better) or as the bottom (worse) of a specific target or reference point they choose.

Fiegenbaum and Thomas (1988) use the prospect of theory to describe behavior at the company level. They found that organizations behave as risk seekers when they are below the target or reference point, but as risk-averse when they are above the reference point. Fiegenbaum et al. (1996) added that the strategic reference point was developed using three dimensions namely the company's internal reference point, the company's external reference point, and time as the company's reference point.

The internal reference dimension is one of the most important factors in the success of a company and for members of the organization. Fiegenbaum et al. (1996) identified this internal capability as the center of gravity of the company which was the driving force of managerial attention. Internal strategic reference points can be developed through means and objectives. Means and objectives are important components of the foundation of strategic reference points (Javalgi et al., 2006). Means are processes designed to convert inputs, such as skills and resources, into desired outcomes (Shoham and Fiegenbaum, 2002).

Apart from internal dimensions, there are external dimensions which are also important for attention. Like the industrial 
economy that makes the company focus on competitors in the industry. The diversity of external factors makes it important for companies to consider three external factors namely competitors, customers, and stakeholders.

The competitor's reference point can be defined at several levels, namely in comparing companies with competitors as a whole, with certain industry groups, with competitors who lead the industry, or with competitors from other industries (Fiegenbaum et al., 1996) . Customers and suppliers are external reference points that need attention. It takes a serious assessment of customer needs and analysis of the company's ability to respond to these needs.

Stakeholders are groups that are outside the company but have an interest in the success or failure of a company. This includes governments, investors, and special interest groups such as trade unions. Companies can use stakeholder strategic reference points, such as the initial application of new government requirements or proactive reduction of environmental pollution, as a marketing tool, to illustrate the company's commitment to local/global communities (Javalgi et al., 2006).

The time dimension can be divided into two main categories namely past and future. The strategic choices that companies make can be greatly influenced by references to the past (where the company is already located), or the future (where the company wants to be). The past is often an important factor in building reference points. Building on past excellence provides a reference point to spur ongoing achievements. Investors and organizational decision-makers look at past performance in conducting evaluations to determine future alternatives (Wahyuni et al., 2016). Besides, using the past as a reference point can also serve to limit strategic options that are considered feasible by organizations (Fiegenbaum et al., 1996).

\subsection{Belief-adjustment theory}

The belief-adjustment theory which states Hogarth and Einhorn (1992) that there are individual reactions to orders and timings or two different information. This theory explains that when two information that has two different information content such as good news and bad news, then investors tend to revise their initial beliefs. This model based on the assumption that when someone processes information in a manner overall and has limitations regarding memory capacity, individuals tend to change their beliefs through the process of adjustment. They stated when individuals obtain new evidence they revise beliefs again with the adjustment process. The Belief Adjustment Model has considered three characteristics, namely direction, strength, and type.

This model explains that the way a person improves his initial beliefs is influenced by various factors. The nature of the evidence considered in this belief-adjustment model is direction, strength, and type. Direction indicates the presence or absence of changes in beliefs over predictions or decisions taken. Strengths are related to the strengths and weaknesses of information patterns affecting decisions. While types are a reflection of information patterns in terms of positive, negative, or mixed information patterns (Wardhani and Almilia, 2012).
Based on belief adjustment theory, it is also said that the factors that cause recency effects are anchoring. Anchoring is prior beliefs. Anchoring is the initial belief. The theory says that high anchoring (low) will decrease (increase) when faced with negative (positive) information when compared to low (high) anchoring (Hartono (2004), Habbe and Mande (2016)). Anchoring Heuristic describes the phenomenon where information greatly influences decisions, especially information that is found at the beginning of a particular situation (Richie and Josephson, 2017). The anchoring effect in a decision has a strong influence and can last long enough even after making irrational decisions. The anchoring effect can occur even if the anchoring value is not informative or unreasonable (Bahnik et al., 2017).

\subsection{Hypothesis development}

In the Capital Market known types of investors are rational and irrational (irrational). Rational investors are investors who only pay attention to the relationship between risk and expected return. While irrational investors are investors who are influenced by other factors, namely psychological factors in this case are cognitive and emotional so that they often cause biases (Wardhani and Almilia, 2012).

The form of multiple benchmark information is present as one solution to reduce the tendency of bias experienced by irrational investors. This form of information is said to be more effective in describing company performance (Schrand and Walther (2000), Krische (2005), Wahyuni and Hartono (2012), Wahyuni et al. (2016), Praditha et al. (2019)) so that investors are better able to predict all considerations and decision to be taken. Besides, the lack of research using multiple benchmark information forms motivates this research to be carried out. In Indonesia alone, the disclosure of this form of multiple benchmark information was previously tested by Wahyuni et al. (2016). Testing with laboratory design is carried out to strengthen the internal validity of the treatment given. This is done because the main objective of this study is to prove the effectiveness of multiple benchmark information in the process of revising investor confidence in predicting the future earnings performance of a company.

Revision of investor confidence is generally influenced by psychological factors, in this case, heuristic psychology. At the very least, investors experience an initial value or initial belief in making consideration or making investment decisions (Bloomfield et al. (2003), Habbe and Mande (2016), Habbe (2017), Richie and Josephson (2017), Sundari et al. (2018), Praditha (2019), Praditha et al. (2019)). Thus the hypothesis proposed in this study is the disclosure of multiple benchmark information helps investors reduce the estimation bias compared to the form of single benchmark information.

\section{RESEARCH METHOD AND DESIGN}

\subsection{Research design}

This research was designed with laboratory experiments. The design of this study involves a variation of the faculty of 
two or more treatments (explanatory variables) so that it can be seen that there is a separation of influence on the variables as well as the potential for interactive influence between explanatory variables.

The design of this study is used to determine whether the form of multiple benchmark information is more effective in helping investors reduce the estimation bias compared to the form of single benchmark information. The experiment was carried out with a $2 \times 2$ full factorial between-subject design as illustrated in the Table 1.

Table 1: Experimental Design

\begin{tabular}{lll}
\hline & SB & MB \\
\hline PE (+) CE (-) & I & II \\
PE (-) CE (+) & III & IV \\
\hline
\end{tabular}

PE: previous earnings

$\mathrm{CE}$ : current earnings

SB: a single benchmark

MB: multiple benchmarks.

Table 1 show that when investors obtain positive PE information and negative $\mathrm{CE}$ in the form of a single benchmark (quadrant I), investors will provide a high level of estimation bias, whereas when given additional information in the form of multiple benchmarks (quadrant II), the estimation bias is reduced. The same thing when investors are presented with negative $\mathrm{PE}$ information and positive $\mathrm{CE}$ in the form of a single benchmark (quadrant III), the estimation is given is biased, whereas when additional information is provided as a complement to the form of multiple benchmark information (quadrant IV), the estimation bias is reduced.

\subsection{Variables and measurement}

The independent variable in this study is the earnings pattern namely information on previous earnings (PE) and current earnings (CE) in two forms, namely the form of a single benchmark and multiple benchmarks. The form of single benchmark information consists of earnings information (PE and CE) plus a description of earnings information. While multiple benchmark information contains profit information, description, and management guidance. Management guidance is a report that presents the company's internal and external information and future projections.

The dependent variable in this study is the estimation error obtained from the difference between estimated earnings and target earnings. Estimated earnings are future earnings predicted by investors whereas target earnings are measured using the Maximum Likelihood Estimate (MLE) regression method based on company earnings information listed on the Indonesia Stock Exchange. Estimated values between two forms of information (single and multiple benchmarks) will be compared to get the magnitude of the estimation bias reduction.

\subsection{Participant}

The experimental subjects in this study were students majoring in accounting and financial management at STIE Tri Dhar- ma Nusantara who had attended a capital market school at the Indonesia Stock Exchange Makassar representative office. Students are proxied as investors assuming that students are welleducated investors but lack experience. This is to control extraneous variables namely experience in the capital market. The number of participants was 40 people who were divided into two groups randomly. Group divisions based on the needs of the experimental case.

\subsection{Treatment and manipulation check}

The treatment used is the development of the treatment used by Wahyuni et al., (2016) and Praditha (2020) by adjusting the manipulation of variables in this study. Manipulation checks use a binary questionnaire (true or false) of three questions to ensure that the subject understands the assignment given. These three questions relate to the form of information presented, the form of assignments provided, and the types of benchmarks used. Error in answering the question, it is considered a failure in checking manipulation.

\subsection{Analysis Method}

Participant characteristics were tested using descriptive statistics while hypotheses were tested in pairs using paired-samples t-test. Besides, additional tests were also conducted with oneway ANOVA.

\section{ANALYSIS AND DISCUSSION}

\subsection{Participant characteristics}

In the initial stages of the experimental procedure, investors are asked to fill in personal data relating to gender and age.

Table 2: Participant Characteristics

\begin{tabular}{|c|c|c|c|}
\hline \multicolumn{2}{|c|}{ Characteristics } & \multirow{2}{*}{$\frac{\text { Freq. }}{22}$} & \multirow{2}{*}{$\begin{array}{l}\% \\
55\end{array}$} \\
\hline & Male & & \\
\hline Gender & Female & 18 & 45 \\
\hline \multirow{4}{*}{ Age } & 20 & 4 & 10 \\
\hline & 21 & 19 & 47.5 \\
\hline & 22 & 15 & 37.5 \\
\hline & 23 & 2 & 5 \\
\hline
\end{tabular}

Table 2 shows that there were 22 male participants and 18 female participants. The age of the participants was dominated by students who were 21 years old as many as 19 people, while the rest were 22 years old as many as 15 people, aged 20 years as many as 4 people, and 2 people aged 23 years.

\subsection{Hypothesis testing}

Hypothesis testing is done by using a paired test to see the magnitude of the estimated error rate made by investors. Tests are conducted based on their respective groups namely group I is a group with a pattern of positive previous earnings information and negative current earnings. While group II is the group 


\begin{tabular}{ccrrr}
\multicolumn{5}{c}{ Table 3: Paired-samples statistics } \\
\hline Group & & $\mathrm{N}$ & Mean & \multicolumn{1}{c}{$\begin{array}{l}\text { Std. } \\
\text { Dev. }\end{array}$} \\
\hline \multirow{2}{*}{ I } & SB & 20 & 202.1 & 36.06 \\
& MB & 20 & 13.7 & 6.58 \\
\hline \multirow{2}{*}{ II } & SB & 20 & -378.4 & 36.82 \\
& MB & 20 & -77.2 & 21.91 \\
\hline
\end{tabular}

with negative Earning Earning information patterns and Positive Current Earning.

In group I, investors are given information in the form of a single benchmark, the estimated error rate generated is 202.1, while when given additional information in the form of management guidance as a form of multiple benchmark information, the estimated error rate drops to 13.7. This positive result shows that investors estimate future earnings higher than the target profit (overestimate). In group I, the estimated error rate of investors who were given information in the form of a single benchmark was -378.4 whereas when given additional information in the form of management guidance as a form of multiple benchmark information, the estimated error rate dropped to 77.2. In contrast to the results in group I, the results in group II are negative, which means that investors estimate future earnings lower than target earnings (underestimate).

Both of these results indicate a decrease in the estimated error rate as evidenced by the value that is getting closer to zero. An error rate close to zero indicates that the prediction made is close to the target value and is therefore considered to have a high degree of accuracy. In other words, the level of bias that occurs is getting smaller. Therefore, it can be concluded that the form of multiple benchmark information can reduce the effect of estimation bias by investors so that the research hypothesis can be supported. This result is confirmed by the significance test shown in Table 4.

\begin{tabular}{lrlrrr}
\multicolumn{7}{c}{ Table 4: Paired samples test } \\
\hline Group & Mean & Std. & t & df & Sig. \\
& & Dev. & & & \\
\hline I & 188.4 & 37.98 & 22.2 & 19 & 0.00 \\
II & -301.2 & 41.71 & -32 & 19 & 0.00 \\
\hline
\end{tabular}

In each experimental group showed the same results ie there is a significant difference between the estimation results based on single benchmark information with multiple benchmark information. The results of this ii are shown in Table 4 where the p-value is $0.00<0.05$.

\subsection{Additional testing}

Additional testing was carried out to ensure that participant characteristics did not become extraneous variables in this experiment.

Table 5 shows that there were no significant differences between the estimation errors made by male and female investors
Table 5: ANOVA one-way (gender)

\begin{tabular}{clrrrr}
\hline Group & & df & $\begin{array}{l}\text { Mean } \\
\text { Square }\end{array}$ & F & Sig. \\
\hline \multirow{2}{*}{ I } & Between & 1 & 169229 & 1.98 & 0.17 \\
& Within & 38 & 85547.7 & & \\
\hline \multirow{2}{*}{ II } & Between & 1 & 5748.6 & 2.52 & 0.12 \\
& Within & 38 & 2283.9 & & \\
\hline
\end{tabular}

in group I and group II. This result is evidenced by the p-value of 0.17 and 0.12 , both of which are worth more than 0.05 or $5 \%$. Thus it can be concluded that gender differences are not confounding variables in this experiment.

\begin{tabular}{|c|c|c|c|c|c|}
\hline Group & & $\mathrm{df}$ & $\begin{array}{l}\text { Mean } \\
\text { Square }\end{array}$ & $\mathrm{F}$ & Sig. \\
\hline \multirow[b]{2}{*}{ I } & Between & 3 & 137336 & 1.64 & 0.19 \\
\hline & Within & 36 & 83556.5 & & \\
\hline \multirow[b]{2}{*}{ II } & Between & 3 & 4175.9 & 1.88 & 0.15 \\
\hline & Within & 36 & 2222.6 & & \\
\hline
\end{tabular}

Table 6 is a test of the age difference of investors against the mistake in estimating profits made by investors. The results show a p-value of 0.19 for the group I and a p-value of 0.15 for group II. Both of these significance values are less than 5\% which means there is no significant difference between the estimation errors made by investors aged 20, 21, 22, and 23 years. Investors have the same error rate. Therefore it can be concluded that the age variation of investors is not an influence in the profit assessment process carried out by investors.

\subsection{Discussion}

These results indicate that the additional information in the form of management guidance as part of the form of multiple benchmark information provided to investors is not able to influence investors to change their predictions. Investors still tend to be pegged to the initial value that is believed to be an anchor. This also means investor predictions tend to experience heuristic bias, in this case, heuristic anchoring-adjustment.

An anchoring-adjustment heuristic is where investors tend to make judgments based on past information (anchoring) and then adjust to the new information obtained (Tversky and Kahneman, 1973). Investors will be pegged by the amount of anchoring value that is used as an initial belief, then make adjustments to the new information received. Anchoring is considered to be very strong as a basic reference so that many people who later become dependent on these values (Bloomfield et al. (2003), Boussaidi (2013), Habbe and Mande (2016), Habbe (2017), Sundari et al. (2018), Praditha et al. (2019)).

Although the results of the research show that there is an anchoring-adjustment heuristic bias experienced by investors in estimating earnings, the magnitude of the bias is proven to be 
different in the form of information presented. The form of single benchmark information is proven to make investors make predictions that are not accurate enough or in other words, the level of estimation bias that occurs is quite large. Whereas when investors are presented with multiple benchmark information, investors are better able to make more accurate assessments. Thus, it can be concluded that the form of multiple benchmark information is more effectively used as a basis for assessment by investors compared to the form of single benchmark information (Schrand and Walther (2000), Krische (2005), Han and Tan (2007), Wahyuni et al. (2016).

The multiple benchmark strategy for earnings announcements is said to be better because the information presented is comprehensive information that is earnings information for the past period, current period earnings, and future information in the form of management guidance. Management guide is an explanation of management related to performance estimation in the form of internal and external activities of the company. Internal activities can take the form of product and service issues, as well as organizational issues, while external activities such as economic conditions and government regulations (Wahyuni et al., 2016).

Management guidelines not only have information content), but are also seen as having better quality information for the future than analyst forecasts. Management guidelines are still voluntary disclosures. Several previous studies have shown that there is a positive relationship between voluntary disclosure and rising stock prices (Baginski et al., 2004).

\section{CONCLUSION}

The form of multiple benchmark information can be used as a form of earnings announcements (earnings announcements). This form of information consists of three dimensions, namely internal, external, and time. This form of information presents comprehensive information because it not only presents information about past and present but also presents information about the future. So that this form of information is more effectively used by stakeholders such as investors in conducting assessments.

As it is known that the information presented in the capital market sometimes makes some investors irrational, which is not influenced by the irrationality of psychologists. Investors tend to act practically which causes their valuations to be inaccurate or biased. This bias can be reduced by the disclosure of comprehensive accounting information. So that this research does not only have implications for individual investors in terms of individual psychology but also for issuers to determine earnings announcement policies.

Apart from the results of research that have practical and theoretical implications, this study has several limitations that can be taken into consideration for future researchers. Future studies can try to carry out tests using field experiments or other methods. Besides, the use of real investors as a subject might give better results or it could even be different.

\section{References}

Alivia, L., Sulistiawan, D., 2010. The Examination of Recency and Knowledge Effect in Stock Investment Decision Making: an Experimental Study. The Indonesian Journal of Accounting Research 13 (1), 45-58.

Baginski, S. P., Hassell, J. M., Kimbrough, M. D., 2004. Why Do Managers Explain Their earning Forecast? Journal of Accounting Research 40, 1-29.

Bahnìk, S., Englich, B., Strack, F., 2017. Anchoring effect. En: Pohl, R. F. (Ed.), Cognitive Illusions: Intriguing Phenomena in Judgement, Thinking and Memory. Routledge.

Bloomfield, R., Libby, R., Nelson, M. W., 2000. Underreactions, overreactions and moderated confidence. Journal of Financial Markets 3 (2), 113-137. URL: https://doi .org/10.1016/S1386-4181(00)00003-3

Bloomfield, R., Libby, R., Nelson, M. W., 2003. Do Investors Overrely on Old Elements of the Earnings Time Series? Contemporary Accounting Research $20(1), 1-31$.

URL: https://doi.org/10.1506/N8T8-9QR7-YUCX-91X2

Boussaidi, R., 2013. Representativeness Heuristic, Investor Sentiment and Overreaction to Accounting Earnings: The Case of the Tunisian Stock Market. Procedia - Social and Behavioral Sciences 81 (1974), 9-21.

URL: https://doi.org/10.1016/j.sbspro.2013.06.380

Fiegenbaum, A., Hart, S., Schendel, D., 1996. Strategic Reference Point Theory. Strategic Management Journal 17 (3), 219-235.

URL: https://doi.org/10.1002/(sici)1097-0266(199603)17: 3<219: : aid-smj806>3.3.co;2-e

Fiegenbaum, A., Thomas, H., 1988. Attitudes Toward Risk and The Risk-Return Paradox: Prospect Theory Explanations. Academy of Management Journal 31 (1), 85-106.

URL: https://doi.org/10.5465/256499

DOI: $10.5465 / 256499$

Habbe, A. H., 2017. Estimation Error of Earnings Information: A Test of Representativeness and Anchoring-adjustment Heuristic. International Journal of Economics and Financial Issues 7 (1), 224-233.

URL: https://dergipark.org.tr/ijefi/issue/32002/353177\# article_cite

Habbe, A. H., Mande, H., 2016. The Effect of Information Sequential and Personality on the Investor Belief Revision (an Experimental Study in Decision Making). PONTE International Scientific Research Journal 72 (10), 150166.

URL: https://doi.org/10.21506/j . ponte. 2016.10.13

Han, J., Tan, H. T., 2007. Investors' reactions to management guidance forms: The influence of multiple benchmarks. Accounting Review 82 (2), 521-543. URL: https://doi.org/10.2308/accr.2007.82.2.521

Hartono, J., 2004. How, Why and When Investors Revise Their Beliefs to Company Information and Their Implications to Firm's Announcement Policy. ANDI, Yogyakarta.

Helson, H., 1964. Adaptation-level theory: an experimental and systematic approach to behavior. Harper Row.

Hogarth, R. M., Einhorn, H. J., 1992. Order effects in belief updating: The belief-adjustment model. Cognitive Psychology 24 (1), 1-55. URL: https://doi .org/10.1016/0010-0285(92) 90002-J

Javalgi, R. G., Kim, S. M., Lundstorm, W. J., 2006. Toward the Development of an Integrative Framework of Subsidiary Success: A Synthesis of the Process and Contingency Models with the Strategic Reference Points Theory. Thunderbird International Business Review 48 (6), 843-866.

URL: https://doi.org/10.1002/tie

Kahneman, D., Tversky, A., 1979. Prospect Theory: An Analysis of Decision under Risk. Econometrica 47 (2), 263-292.

Krische, S. D., 2005. Investors' Evaluations of Strategic in Earnings Announcements. The Accounting Review 80 (1), 243-268.

URL: https: //www.jstor.org/stable/4093168

Ordóez, L. D., Connolly, T.and Coughlan, R., 2000. Multiple reference points in satisfaction and fairness assessment. Journal of Behavioral Decision Making 13 (3), 329-344.

URL: https://doi.org/10.1002/1099-0771(200007/09)13: 3<329: : AID-BDM356>3.3. C0; $2-\mathrm{H}$

DOI: $10.1002 / 1099-0771(200007 / 09) 13: 33.3 . C 0$

Praditha, R., 2019. Pola dan Estimasi Laba dalam Heuristik Representativeness (Studi Eksperimen dalam Peramalan Laba Masa Depan). Jurnal Riset Akuntansi Jambi 2 (1), 14-23.

Praditha, R., Habbe, A. H., Rura, Y., 2019. Earnings Estimation: Cognitive Psychology and Investor Reaction. American International Journal of 
Business and Management 2 (11), 89-95.

URL: https://www.aijbm.com/wp-content/uploads/2019/11/ $\mathrm{J} 2118995 \cdot \mathrm{pdf}$

Ratmono, D., Cahyonowati, N., 2005. Anomali Pasar Berbasis Earnings dan Persistensi Abnormal Akrual. En: Simposium Nasional Aakuntansi VIII, September. pp. 379-395.

Richie, M., Josephson, S. A., 2017. Quantifying Heuristic Bias: Anchoring, Availability, and Representativeness. Teaching and Learning in Medicine 30 (1), 67-75.

URL: https : //doi .org/10.1080/10401334.2017.1332631

Rura, Y. and Subroto, B. and Sudarma, M. andRosidi, t. . P., 2011. Jurnal Akuntansi Multiparadigma 2 (2), 261-278.

Schrand, C. M., Walther, B. R., 2000. Strategic Benchmarks in Earnings Announcements: The Selective Disclosure of Prior-Period Earnings Components We have received helpful comments from Ray Ball. The Accounting Review 75 (2), 151-177.

Shoham, A., Fiegenbaum, A., 2002. Competitive determinants of organizational risk-taking attitude: the role of strategic reference points. Management Decision 40 (2), 127-141.

URL: https : //doi .org/10.1108/00251740210422802

Sitinjak, E. L. M., 2013. Perilaku investor individu dalam pembuatan keputusan investasi saham: efek disposisi dan informasi akuntansi. Jurnal Organisasi Dan Manajemen 9 (1), 31-53.

Sundari, S., Mediaty, Habbe, A. H., Harryanto, 2018. Heuristic of Representativeness and Anchoring-Adjustment in Budgeting. International Journal of Academic Research in Accounting, Finance and Management Sciences 8 (4), 52-60.

URL: https : //EconPapers .repec .org/RePEc : hur : ijaraf : v : 8:y: 2018: i : $4: \mathrm{p}: 52-60$

Thibaut, J. W., Kelley, H. H., 2017. The Social Psychology of Groups. Routledge, In.

Tversky, A., Kahneman, D., 1973. Judgements under uncertainty: Heuristics and biases. Judgement Under Uncertainty: Heuristics and Biases 13 (1), 201-210.

URL: https : //doi .org/10.1016/0732-118x(84)90024-2

Wahyuni, S., Hartono, J., 2012. Reminder Effect and Anchoring-Adjustment in earnings announcements: Implementation of Prior-Period Benchmark Disclosure Strategy. Journal of Indonesian Economy and Business 27 (3), 390405 .

Wahyuni, S., Hartono, J., Nahartyo, E., 2016. Implementasi Strategi Pengungkapan Informasi Laba Patok Duga Tunggal dan Multipel dalam Rerangka Teori Titik Acuan Ganda. En: Simposium Nasional Akuntansi XIX. pp. 1-30.

Wardhani, D. A. K., Almilia, L. S., 2012. The Predictive Power of Earnings and Cash Flows (Testing At the Every Stage of Company'S Life Cycle). The Indonesian Accounting Review 3 (01), 9.

URL: https://doi.org/10.14414/tiar.v3i01.208

Wisudanto, Baihaqi, F. R., 2016. Perilaku Loss Aversion Studi Kasus Pada Pasar Modal di Indonesia. En: FMI 8 Palu. 